\title{
MINERALS AND PHENOLIC COMPOUNDS OF CAGAITA FRUITS AT DIFFERENT MATURATION STAGES (Eugenia dysenterica) ${ }^{1}$
}

\author{
MAYARA NEVES SANTOS GUEDES ${ }^{2 *}$, JOSÉ CARLOS MORAES RUFINI ${ }^{3}$, \\ TAMARA REZENDE MARQUES ${ }^{4}$, JÚLIO ONÉSIO FERREIRA MELO ${ }^{5}$, \\ MARTHA CRISTINA PEREIRA RAMOS ${ }^{6}$, RENATA ELISA VIOL ${ }^{7}$
}

ABSTRACT - Cerrado is the largest biome in the state of Minas Gerais-Brazil, represented by a biodiversity of fruit species, especially cagaita (Eugenia dysenterica). Cagaita fruits are considered an important option for fruit growing, because they are source of phenolic compounds with antioxidant properties and mineral content that can contribute with beneficial health effects. In this study, phenolic compounds were characterized by high-performance liquid chromatography and the mineral content of ripe and unripe cagaita fruits was evaluated. Regarding minerals, ripe and unripe fruits stand out due to their high potassium content. Unripe fruits are rich in boron while ripe fruits are source of this mineral. ripe and unripe cagaita fruits have the following phenolic compounds: gallic, caffeic, vanillic, $p$-coumaric, siringeic, ferulic and salicylic acids, epicatechin, quercetin and rutin, the highest contents of these compounds are caffeic, $p$-coumaric, siringeic and ferrulic, epicatechin and rutin identified in unripe fruits, while ripe fruits have high contents of gallic, vanillic and quercetin acids. Thus, cagaita fruits have great potential for food, therapeutic and medicinal applications bringing health benefits.

Index terms: Cerrado fruits, Myrtaceae, HPLC-Uv.

\section{MINERAIS E COMPOSTOS FENÓLICOS EM DIFERENTES ESTÁDIOS DE MATURAÇÃO DE FRUTOS DE CAGAITEIRA (Eugenia dysenterica)}

\begin{abstract}
RESUMO - O Cerrado é o maior bioma no Estado de Minas Gerais-Brasil, representado uma biodiversidade de espécies frutíferas, destacando a cagaiteira (Eugenia dysenterica). Frutos de cagaiteira são considerados uma opção importante para fruticultura, por apresentarem fonte de compostos fenólicos com propriedades antioxidantes e teores de minerais que podem contribuir com efeitos benéficos à saúde. Neste estudo, caracterizaram-se os compostos fenólicos por cromatografia líquida de alta eficiência e avaliaram-se os teores de minerais presentes em frutos de cagaiteira em estádio de maturação maduros e verdes. Em relação aos minerais, frutos maduros e verdes destacam-se por serem ricos em potássio. Os frutos verdes são ricos em boro, enquanto os frutos maduros são fonte desse mineral. Nos frutos de cagaiteira maduros e verdes, foram identificados os compostos fenólicos: os ácidos gálico, cafeico, vanílico, $p$-cumárico, siríngico, ferúlico e salicílico, epicatequina, quercetina e rutina, sendo os maiores teores dos compostos os ácidos cafeico, $p$-cumárico, siríngico e ferúlico, epicatequina e rutina identificados nos frutos verdes, enquanto para frutos maduros o destaque foi para os ácidos gálico, vanílico esalicílico e quercetina. Assim, frutos de cagaita podem apresentar grande potencial para aplicações alimentares, terapêuticas e medicinais, trazendo benefícios à saúde.
\end{abstract}

Termos de indexação: Frutos do cerrado, Myrtaceae, CLAE-Uv.

(Paper 192-15). Received July 31, 2015. Accepeted: November 03, 2015.

${ }^{2}$ Agronomist, Post-doctoral student, Agrarian Sciences Department, Federal University of São João Del Rei - UFSJ. Caixa Postal 56, CEP. 35760-970, Sete Lagoas - Mg. E-mail: maysantos2@yahoo.com.br

${ }^{3} \mathrm{PhD}$, Teacher of the Federal University of São João Del Rei - UFSJ. Caixa Postal 56, CEP. 35760-970, Sete Lagoas - MG. E-mail: rufini@ufsj.edu.br

${ }^{4}$ Chemistry, Post-doctoral student, Chemicals Departament, Federal University of Lavras - UFLA, Caixa Postal 3037, 37200-000, Lavras-MG. E-mail: tamara_rezende@hotmail.com

${ }^{5} \mathrm{PhD}$, Teacher of the Federal University de São João Del Rei - UFSJ. Caixa Postal 56, CEP. 35760-970, Sete Lagoas - Mg. E-mail: onesiomelo@gmail.com

${ }^{6}$ Agronomist, Doctoral student, Plant Science Departament, Federal University of Lavras - UFLA, Caixa Postal 3037, 37200-000, Lavras-MG. E-mail: marthinha.ramos@yahoo.com.br

${ }^{7}$ Agronomis, Master student, Agrarian Sciences Department, Federal University of São João Del Rei - UFSJ. Caixa Postal 56, CEP. 35760-970, Sete Lagoas - Mg. E-mail: renataviol@live.com 


\section{INTRODUCTION}

Exotic or native Brazilian fruits present great nutritional, economic and social potential. These fruits are extractivistically exploited and as they are seasonal, large post-harvest losses occur. Cagaita (Eugenia dysenterica Dc) is a typical fruit of this scenario, belonging to the family Myrtaceae, native of the Brazilian cerrado. Its fruiting period occurs between October and December; its fruits are globose, pale yellowish, slightly acidic, with membranous epicarp, weighing between 14 and $20 \mathrm{~g}, 3$ to $4 \mathrm{~cm}$ in length and 3 to $5 \mathrm{~cm}$ in diameter (ROESLER et al., 2007).

Cagaita fruits are consumed fresh or processed and present medicinal properties in their leaves and barks (SILVA et al., 2001). Its leaves are used as antidiarrheals while their fruits have laxative properties according to the popular use (LIMA et al., 2010; VIEIRA et al., 2012). Studies indicate that cagaita fruits are highly nutritious, contain $90 \%$ water, low caloric value $(36.6 \mathrm{Kcal}), 5.9 \%$ carbohydrates, source of functional compounds such as vitamin $\mathrm{C}$ and $\beta$-carotene and phenolic compounds such as flavonoids, which are antioxidant and anti-mutagenic substances (ROESLER et al., 2007, CARDOSO et al., 2011 and ROCHA et al., 2013). Another peculiar characteristic of this fruit is its contens of phenolic compounds and minerals. According to Morgano et al. (1999) and Silva et al. (2008), cagaita fruits are considered important sources of minerals.

The minerals present in these fruits bring many health benefits, regulating the metabolism of various enzymes, acid-base balance, osmotic pressure, muscle and nerve activity, facilitating the transfer of essential compounds through the membranes. In some cases, minerals are part of the tissue constituent elements and are necessary to the vital process and must be contained in food in adequate amounts and proportions (ROSS et al., 2014). Phenolic compounds provide attributes such as color, texture, bitterness, astringency and functional properties to fruits such as antioxidant properties (EVERETTE et al., 2010). Even in small amounts, these compounds have physiological effects through their antioxidant action, playing an important role in the processes of inhibiting the risk of cardiovascular diseases and of several chronic degenerative diseases, such as diabetes, cancer and inflammatory processes (IMHO, KHOKHAR, 2002 and NINFALI et al., 2005).

In view of the above and considering the absence of studies reporting the phenolic composition and mineral content in cagaita fruits (Eugenia dysenterica Dc), the aim of the present study was to characterize the phenolic compounds by highperformance liquid chromatography and to evaluate the mineral content present in cagaita fruits at two maturation stages, ripe and unripe, in order to obtain data of nutritional interest that can allow the best use of fruits as raw material.

\section{MATERIAL AND METHODS}

Cagaita fruits were manually and randomly collected from plants at the Federal University of São João Del Rei - UFSJ in the municipality of Sete

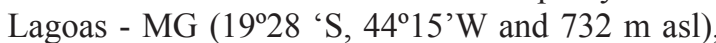
during the 2014 harvest. The climatic classification of the region is Aw type (Köppen), typical of savannah, with dry winter and average air temperature of the coldest month above $18^{\circ} \mathrm{C}$.

Fruits were harvested according to their maturation stage determined by the external visual appearance of fruits as unripe (green coloration) and ripe fruits (yellow coloration). Fruits were selected for the formation of experimental units. For each stage of maturation, four replicates of $200 \mathrm{~g}$ of fruits were used. Samples were ground and homogenized in a Mix-type Arno multiprocessor and stored in freezer at $-18^{\circ} \mathrm{C}$ and $90-95 \%$ relative humidity until moment of analyses. Each replicate was analyzed in triplicate.

The experimental design was completely randomized, with four replicates. Independent variables were the different maturation stages and dependent variables were contents of minerals and phenolic compounds.

Mineral content-The levels of macrominerals $(\mathrm{P}, \mathrm{K}, \mathrm{Ca}, \mathrm{S}$ and $\mathrm{Mg})$ and microminerals $(\mathrm{Cu}$, $\mathrm{Mn}, \mathrm{Zn}, \mathrm{B}$ and $\mathrm{Fe}$ ) were determined according to Embrapa (2009). Extracts were obtained by nitroperchloric digestion. $\mathrm{P}$ and $\mathrm{S}$ were determined by colorimetry according to AOAC (2005) method; $\mathrm{Fe}, \mathrm{Zn}, \mathrm{Mn}, \mathrm{Cu}, \mathrm{Mg}, \mathrm{B}$ and $\mathrm{Ca}$ by atomic absorption spectrophotometry and $\mathrm{K}$ by flame photometry. Results were expressed in milligrams per $100 \mathrm{~g}$ of fresh fruit, $\left(\mathrm{mg} .100 \mathrm{~g}^{-1}\right)$.

Phenolic compounds - Milli-Q ultrapure water (Millipore, Billerica, MA, USA), acetic acid and HPLC grade methanol (Merck) were used to prepare the mobile phase used in the HPLC analyses. The standard HPLC grade phenolic compounds were: gallic, $p$-coumaric, ferulic, siringeic and salicylic acids and condensed tannin monomers epicatechin and quercetin were purchased from Sigma-Aldrich. Vanillic acid was obtained from Fluka. Standard stock solutions were prepared in HPLC grade methanol (Merck). 
Extraction - Extracts of fresh cagaita fruits were performed according to Arabbi et al. (2004) with some modifications using a methanol / water solution $(70: 30 \mathrm{v} / \mathrm{v})$ at $1: 15(\mathrm{~m} / \mathrm{v})$, stirred for 10 minutes in ice bath.

Separation, identification and quantification of phenolic compounds - The equipment used was HPLC Shimadzu model L201147, the best response was obtained at wavelength of $280 \mathrm{~nm}$. Samples and standards were injected onto a Kromasil column (4.6 mm x $250 \mathrm{~mm}$ ).

The mobile phase consisted of the solutions of acetic acid in water $2 \%(\mathrm{~A})$ and methanol: water: acetic acid (70: 28: $2 \mathrm{v} / \mathrm{v} / \mathrm{v})(\mathrm{B})$. Analyses were performed with total time of 60 minutes, temperature of $40^{\circ} \mathrm{C}$, flow of $1.25 \mathrm{~mL} \mathrm{~min}^{-1}$ and injection volume of $20 \mu \mathrm{L}$ in gradient type system $(100 \%$ solvent $\mathrm{A}$ from 0.01 to 5 minutes, $70 \%$ of solvent $\mathrm{A}$ from 5.0 to 25.0 minutes, $60 \%$ of solvent $\mathrm{A}$ from 25.0 to 43.0 minutes, $55 \%$ of solvent A from 43.0 to 50.0 minutes and $0 \%$ of solvent $A$ for 10 minutes) until the end of the run. Solvent A was increased to $100 \%$ in order to balance the column.

Cagaita fruit extracts and standards were filtered on a $0.22 \mu \mathrm{m}$ nylon membrane (Millipore ${ }^{\circledR}$ ) and directly injected into the chromatographic system three times in order to obtain the mean concentrations and the retention times.

Phenolic compounds in the extract were identified by comparison with the retention times of standards and confirmed by co-chromatography of extracts and standards. For the quantification of phenolic compounds, the external standardization method was used with concentrations of standard stock solutions: gallic acid (170.12 mg. $\left.\mathrm{L}^{-1}\right)$, quercetin (302.23 mg. $\left.\mathrm{L}^{-1}\right)$, epicatechin $\left(290.24 \mathrm{mg} . \mathrm{L}^{-1}\right)$, vanillic acid (168.14 mg. $\left.\mathrm{L}^{-1}\right)$, ferulic acid (194.18 mg. $\left.\mathrm{L}^{-1}\right)$, syringic acid (198.17 mg. $\left.\mathrm{L}^{-1}\right)$, salicylic acid (138.12 mg. $\left.\mathrm{L}^{-1}\right)$, caffeic acid (180.16 mg.L $\left.\mathrm{L}^{-1}\right)$, rutin (610.52 mg.L $\left.\mathrm{L}^{-1}\right), p$-coumaric acid (164.16 mg.L $\mathrm{L}^{-1}$ ) (Figure 2). Quantification was performed through the construction of analytical curves obtained by linear regression using the Origin 6.1 software (OriginLab, Northampton, MA, USA).

\section{RESULTS AND DISCUSSION}

The results of the mineral composition of cagaita fruits at different maturation stages are in Table 1. The amount of phosphorus and zinc observed in this work did not vary as a function of the maturation degree of fruits, which contents are less sensitive to the maturation advancement. The other minerals, potassium, calcium, magnesium, sulfur, iron, manganese, copper and boron, presented higher contents in unripe fruits, which increases its potential for processing, since cagaita fruits are usually processed unripe.

Potassium was the most abundant mineral in fruits, with overall mean content of $831.89 \mathrm{mg} .100 \mathrm{~g}^{-1}$ (Table 1). This element presents great mobility in plants due to its little affinity to form organic chelates, thus it is present in large amounts in plant tissues (VANILLO et al., 2006). Potassium is an important component in the formation of many proteins and is linked to the metabolism of carbohydrates, being part of several enzymatic processes.

As in most fruits, calcium and boron accumulation is limited to initial stages of development that coincide with cell division, which explains the higher calcium and boron levels in unripe fruits when compared to ripe fruits (Table 1). Calcium is the main element in the cell wall composition of fruits, while boron is an important constituent of the structure of the polysaccharides that provide resistance to the cell wall, and both have the function of maintaining the cell wall integrity and permeability (HAWKESFORD et al., 2002, TAIZ and ZEIGER, 2009).

Magnesium, sulfur, copper, manganese and iron are part of the chlorophyll molecule. Magnesium is one of the main components of chlorophyll, while copper, manganese and iron are required for chlorophyll synthesis, being present in higher concentration in unripe fruits. Thus, as the fruit matures, there is degradation of chlorophyll, responsible for the green coloration of fruits, with consequent reduction of magnesium, sulfur, copper, manganese and iron molecules (HAWKESFORD et al., 2002, MALAVOLTA et al., 2002, TAIZ and ZEIGER, 2009, OETTERER et al., 2006), as observed in this study (Table 1).

According to the National Agency of Health Surveillance - ANVISA (BRASIL 2005), food, "with minimum of $15 \%$ of the Daily Recommended Intake (DRI) per $100 \mathrm{~g}$ of solid food" is considered source of minerals, and food "with minimum of $30 \%$ of the reference DRI per $100 \mathrm{~g}$ of solid food" is considered rich in minerals. Thus, cagaita fruits are not considered as a good source of minerals, phosphorus, calcium, magnesium, sulfur, zinc manganese and copper.

Unripe cagaita fruits provide equivalent to $55.5 \%$ of the daily requirements of boron, showing that it is rich in this nutrient, while ripe fruits provide $16.6 \%$ of the daily requirement, being source of this nutrient (Table 1). The consumption of boron is of great importance for humans, because the 
consumption of boron brings beneficial effects on the central nervous system, acts in the reduction of some types of cancer, has hormonal function, helps in the absorption of vitamin $\mathrm{D}$ and production of insulin in addition to action in the prevention and reduction of arthritis (NIELSEN, 2014).

Unripe and ripe cagaita fruits are rich in potassium, a contribution equivalent to more than $30 \%$ the daily requirement (Table 1). Potassium is the major intracellular cation that contributes to the metabolism and synthesis of proteins and glycogen (SHIN et al., 2013). The potassium content 190 found in this work for cagaita fruits is close to those found for unripe banana flour 191, considered as a rich source of potassium (BORGES et al., 2009).

Cagaita fruits provide high contents of minerals, such as potassium, copper, manganese and iron, in relation to fruits of the same family, such as guava, an already domesticated fruit species (FREIRE et al., 2012).

Phenolic acids are widely present in plant materials, as secondary metabolites in the free form or linked to glycosides of soluble and insoluble esters, presenting biological activities, such as anticancer, antibacterial and antioxidant activity (HUANG et al., 2015). Phenolic compounds provide cell wall support materials (lignin) and under normal maturation conditions, their levels are higher during fruit growth and decrease with maturation (SELVARAJ and KUMAR, 1989). Similar results for phenolic compounds were found for cagaita fruits (ROCHA et al., 2011).

The following phenolic compounds were identified in unripe and ripe cagaita fruits: gallic, caffeic, vanillic, $p$-coumaric, syringic, ferulic and salicylic acids, epicatechin, quercetin and rutin (Figure 1). Gallic acid is a monomer of hydrolysable tannins, while epicatechin is a monomer of condensed tannins. There are several other peaks in which substances were not identified due to a lack of phenolic standards for comparison.

In cagaita fruits at ripe maturation stage, the contents of phenolic compounds gallic, vanillic and salicylic acids were higher than those found in unripe fruits, while the levels of epicatechin, rutin, and caffeic, $p$-coumaric, syringic and ferulic acids were prominent in unripe cagaita fruits. In both maturation stages, epicatechin presented high content (Table 2).

These results corroborate results found by Barboni et al. (2010), who identified high epicatechin levels in Myrtus communis L., a species also of the family Myrtaceae. The functionality of phenolic compounds is mainly related to their antioxidant action, that is, free radical scavenger and, therefore, may be associated with the prevention of various diseases such as some types of cancers and cardiovascular diseases (KARAKAYA, 2004; NINFALI et al. 2005), and action in the prevention of obesity (GHOLAMHOSEINIAN et al., 2010).

Tannins such as gallic acid and epicatechin and flavonoids such as quercetin contain a variety of hydroxyl groups and show high antioxidant capacity and elimination of free radicals. Flavonoids are capable of altering the kinetics of lipid peroxidation by modifying the organization of lipid compounds (MITTAL et al., 2014). Flavonoids have ideal structures for the sequestration of free radicals, being considered antioxidants more effective than vitamins $\mathrm{E}$ and C (BARREIROS et al., 2006).

Tannins have strong interactions with metal ions and macromolecules, such as polysaccharides, and the ability to form soluble complexes with several proteins such as digestive enzymes (GHOLAMHOSEINIAN et al., 2010). This ability of tannins to interact with proteins makes this class of substances potent inhibitors of digestive enzymes. Wenzel (2013) reported that quercetin appears to be a promising inhibitor of enzymes, limiting carbohydrate digestion and acting controlling postprandial blood glucose levels. These phenolic compounds were identified in cagaita fruits, thus confirming the medicinal properties according to popular use.

Fruit consumption is the main source of phenolic acids in the diet, as compared to vegetables and grains, as fruits are richer in phenolic acids, which normally have high antioxidant activity (FUKUJI et al., 2010). Unripe and ripe cagaita fruits are rich in phenolic compounds and in addition to their content of minerals make them a promising source of bioactive compounds, with antioxidant, anti-obesity and nutritive action, so cagaita cultivation should be stimulated (Figure 2). 
TABLE 1- Content of minerals and Daily Recommended Intake (DRI) of minerals (mg / day) for adults and mineral contribution for DRI (\%) in relation to $100 \mathrm{~g}$ of cagaita fruits.

\begin{tabular}{|c|c|c|c|c|c|}
\hline \multirow[b]{3}{*}{ Phosphorus } & \multicolumn{2}{|c|}{ Minerals(mg.100g-1) } & \multirow[b]{2}{*}{ DRI (mg) } & \multirow[b]{2}{*}{$\begin{array}{c}\text { DRI (\%) } \\
\text { Ripe fruits }\end{array}$} & \multirow[b]{2}{*}{$\begin{array}{c}\text { DRI (\%) } \\
\text { Unripe fruits }\end{array}$} \\
\hline & Ripe fruits & Unripe fruits & & & \\
\hline & $75.53 \mathrm{a}$ & 82.96 a & 800.0 & $9.44 \mathrm{a}$ & $10.37 \mathrm{a}$ \\
\hline Potassium & $767.27 \mathrm{~b}$ & $896.5 \mathrm{a}$ & 2500.0 & $30.69 \mathrm{~b}$ & $35.86 \mathrm{a}$ \\
\hline Calcium & $27.16 \mathrm{~b}$ & $44.52 \mathrm{a}$ & 800.0 & $3.39 \mathrm{~b}$ & $5.57 \mathrm{a}$ \\
\hline Magnesium & $20.37 \mathrm{~b}$ & $26.66 \mathrm{a}$ & 300.0 & $6.79 \mathrm{~b}$ & $8.88 \mathrm{a}$ \\
\hline Sulfur & $40.06 \mathrm{~b}$ & $52.53 \mathrm{a}$ & 500.0 & $8.01 \mathrm{~b}$ & $10.50 \mathrm{a}$ \\
\hline Zinc & $0.76 \mathrm{a}$ & $0.77 \mathrm{a}$ & 15.0 & $5.06 \mathrm{a}$ & $5.13 \mathrm{a}$ \\
\hline Iron & $0.91 \mathrm{~b}$ & $1.96 \mathrm{a}$ & 14.0 & $6.5 \mathrm{~b}$ & $12.20 \mathrm{a}$ \\
\hline Manganese & $0.41 \mathrm{~b}$ & $0.61 \mathrm{a}$ & 5.0 & $8.31 \mathrm{~b}$ & $12.36 \mathrm{a}$ \\
\hline Copper & $0.27 \mathrm{~b}$ & $0.44 \mathrm{a}$ & 3.0 & $9.00 \mathrm{~b}$ & $14.66 \mathrm{a}$ \\
\hline Boron & $0.30 \mathrm{~b}$ & $1.0 \mathrm{a}$ & 1.8 & $16.66 \mathrm{~b}$ & $55.55 \mathrm{a}$ \\
\hline
\end{tabular}

Means followed by the same letter in rows do not statistically differ from each other by the Tukey test at $5 \%$ probability $(\mathrm{P} \leq 0.05)$.

TABLE 2-Concentrations of phenolic acids identified in ripe and unripe cagaita fruits.

\begin{tabular}{|c|c|c|c|}
\hline \multirow{2}{*}{ Number } & \multirow{2}{*}{ Compound } & \multicolumn{2}{|c|}{ Cagaita fruits $\left(\mathrm{mg} .100 \mathrm{~g}^{-1}\right)$} \\
\hline & & Ripe & Unripe \\
\hline 1 & Gallic acid & $6.04 \mathrm{a}$ & $5.76 \mathrm{~b}$ \\
\hline 2 & Caffeic acid & $0.28 \mathrm{a}$ & $1.57 \mathrm{a}$ \\
\hline 3 & Vanillic Acid & $8.51 \mathrm{a}$ & $7.03 \mathrm{~b}$ \\
\hline 4 & Epicatechin & $68.17 \mathrm{~b}$ & $75.19 \mathrm{a}$ \\
\hline 5 & $p$-coumaric acid & $2.79 \mathrm{~b}$ & $20.92 \mathrm{a}$ \\
\hline 6 & Syringing acid & $1.66 \mathrm{~b}$ & $2.50 \mathrm{a}$ \\
\hline 7 & Ferulic acid & $0.37 \mathrm{~b}$ & $0.61 \mathrm{a}$ \\
\hline 8 & Salicylic acid & $18.37 \mathrm{a}$ & $17.55 \mathrm{~b}$ \\
\hline 9 & Quercetin & $22.10 \mathrm{a}$ & $14.97 \mathrm{~b}$ \\
\hline 10 & Rutin & $4.50 \mathrm{~b}$ & $4.55 \mathrm{a}$ \\
\hline
\end{tabular}

Means followed by the same letter in rows do not statistically differ from each other by the Tukey test at $5 \%$ probability $(\mathrm{P} \leq 0.05)$. 

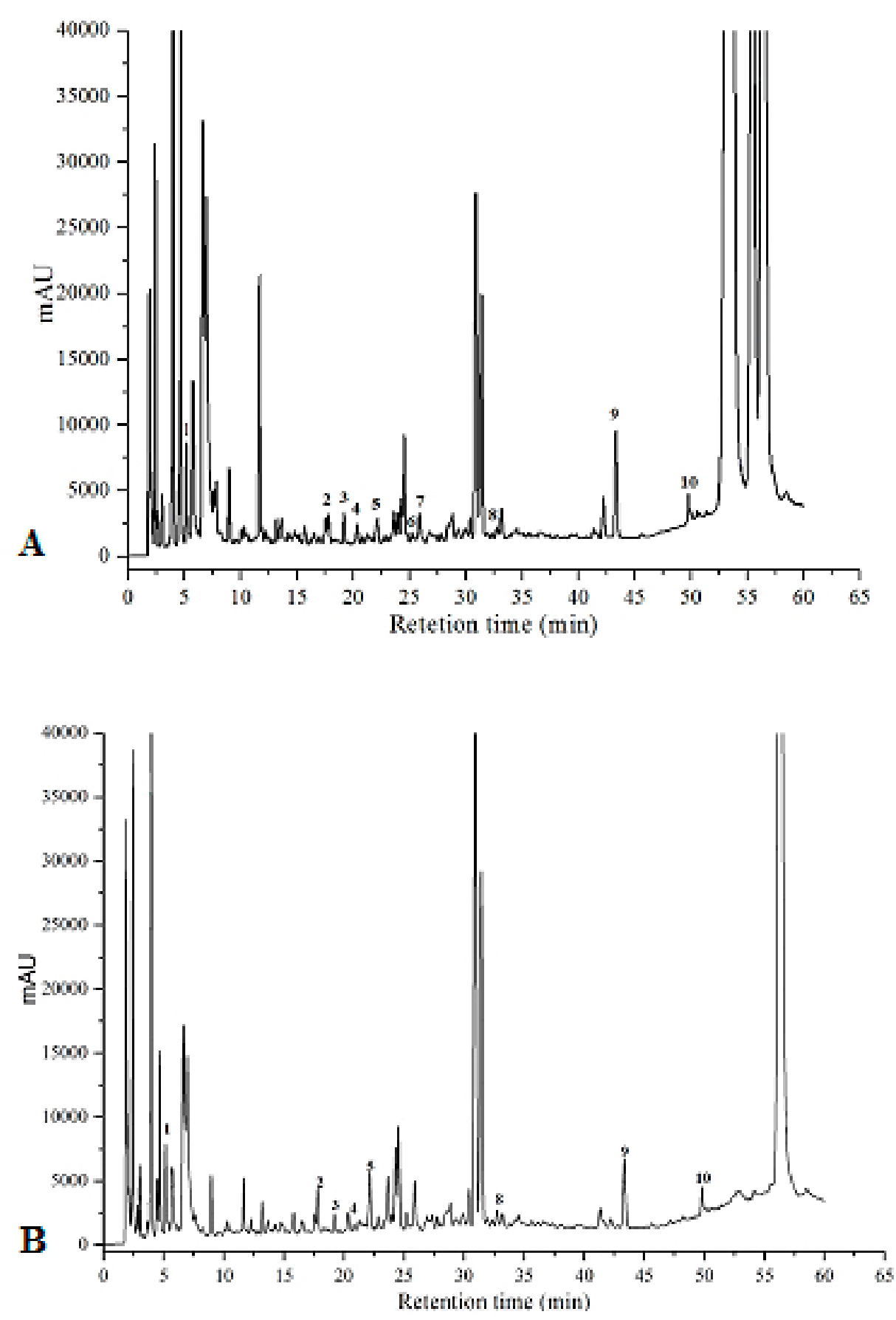

FIGURE 1- Chromatographic profile by HPLC-Uv the ripe (A) and unripe (B) cagaita fruits. Os phenolic acids são: (1) gallic acid, (2) caffeic acid, (3) vanillic acid, (4) epicatechin, (5) $p$-coumaric acid, (6) syringig acid, (7) ferulic acid, (8) salicylic acid, (9) quercetin, (10) rutin. 


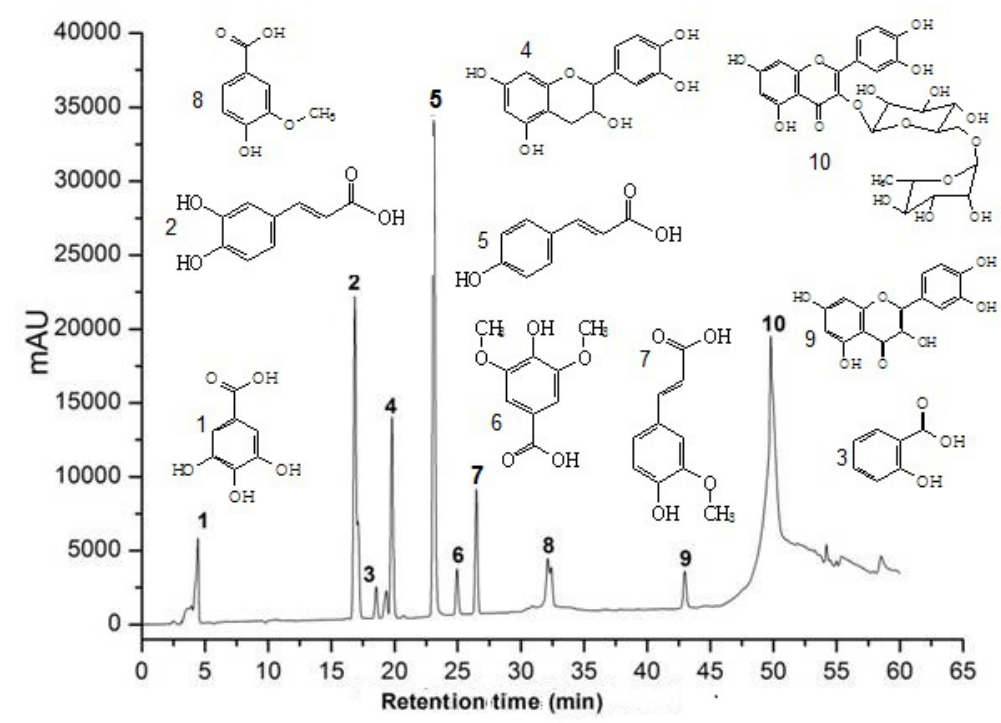

FIGURE 2 - Chromatographic profile by HPLC-Uv standards of a mixture of phenolic acids a $280 \mathrm{~nm}$. Os phenolic acids são: (1) gallic acid, (2) caffeic acid, (3) vanillic acid, (4) epicatechin, (5) p-coumaric acid , (6) syringig acid, (7) ferulic acid , (8) salicylic acid, (9) quercetin, (10) rutin.

\section{CONCLUSION}

Unripe and ripe cagaita fruits have the following phenolic compounds: gallic, caffeic, vanillic, $p$-coumaric, syringic, ferulic and salicylic acids, epicatechin, quercetin and rutin. In both maturation stages, epicatechin is present in high content.

Unripe and ripe cagaita fruits stand out due to their high potassium content. For boron, unripe and ripe cagaita fruits are considered source of this mineral.

Thus, the consumption of cagaita should be stimulated as a promising source of bioactive compounds with significant potential to be exploited in food, therapeutic and medicinal applications, bringing health benefits.

\section{REFERENCES}

AOAC - ASSOCIATION OFFICIALANALYTICAL CHEMISTRY. Official methods of analysis of the Association of Official Analytical Chemistry. $19^{\text {th }}$ ed. Arlington: AOAC Internacional, 2012. 1015p.

ARABBI, P.R.; GENOVESE, M.I.; LAJOLO, F.M. Flavonoids in vegetable foods commonly consumed in Brasil and estimated ingestion by the Brazilian population, Journal of Agricultural and Food Chemistry, Washington, v.53, n. p.1124:1131, 2004.
BARBONI, T.; CANNAC, M.; MASSI, L.; PEREZRAMIREZ, Y.; CHIARAMONTI, N. Variability of polyphenol compounds in Myrtus communis L. (Myrtaceae). berries from Corsica. Molecules, Paris, v.15, n.11, p.7849-7860, 2010.

BARREIROS, A.L.B.S.; DAVID, J.M.; DAVID, J.P. Estresse oxidativo: Relação entre geração de espécies reativas e defesa do organismo. Química Nova, São Paulo, v.29, n.1, p.113-123, 2006.

BORGES, A.M.; PEREIRA, J.; LUCENA, E.M.P. Caracterização da farinha de banana verde. Ciências Tecnologia Alimentos, Campinas, v. 29, n.2, p.333339, 2009.

BRASIL. Ministério da Saúde. Agência Nacional de Vigilância Sanitária - ANVISA. RDC n ${ }^{\circ} 269$, de 22 de setembro de 2005. Aprova o regulamento técnico sobre a Ingestão Diária Recomendada (IDR) de proteína, vitaminas e minerais. Diário Oficial da União, Poder Executivo, Brasília, DF, 23 set. 2005.

CARDOSO, L.M.; MARTINO, H.S.D.; MOREIRA, A.V.B.; RIBEIRO, S.M.R.; PINHEIRO-SANT'ANA, H.M. Cagaita (Eugenia dysenterica DC.) of the Cerrado of Minas Gerais, Brazil: Physical and chemical characterization, carotenoids and vitamins.

Food Research International, Barking, v.44, p.2151-2154, 2011. 
EMBRAPA - Empresa Brasileira de Pesquisa Agropecuária. Manual de análises químicas de solos, plantas e fertilizantes. 2.ed. rev. ampl. Brasília, DF: Embrapa Informação Tecnológica, 2009. 627p.

EVERETTE, J.D.; BRYANT, Q.M.; GREEN, A.M.; ABBEY, Y.A.; WANGILA, G.W.; WALKER, R.B. Thorough study of reactivity of various compound classes toward the Folin-Ciocalteou reagent. Journal of Agricultural and Food Chemistry, Washington, v.58, p.8139-8144, 2010.

FREIRE, J.M.; ABREU, C.M.P de.; CORRÊA, A.D.; SIMÃO, A.A.; SANTOS, C.M. dos. Avaliação de compostos funcionais e atividade antioxidante em farinhas de polpa de goiabas. Revista Brasileira de Fruticultura, Jaboticabal, v.34, n.3, p.847-852, 2012.

FUKUJI, T.S.; TONIN, F.G.; TAVARES, M.F.M. Optimization of a method for determination of phenolic acids in exotic fruits by capillary electrophoresis. Journal of Pharmaceutical and Biomedical Analysis, Amsterdam, v.51, n.2, p.430438,2010

GHOLAMHOSEINIAN, A.; SHAHOUZEHI, B.; SHARIFI-FAR, F. Inhibitory effect of some plant extracts on pancreatic lipase. International Journal of Pharmacology, Fasialabad, v.6, p.18-24, 2010.

HAWKESFORD, M.; HORST, W.; KICHEY, T.; LAMBERS, H.; SCHJOERRING, J.; MØLLER, I. S.; WHITE, P. Functions of macronutrients. In: MARSCHNER, P. (Ed.). Marschner's mineral nutrition of higher plants. $3^{\text {rd }}$ ed. San Diego: Academic Press; 2002. p.135-189.

HUANG, R.T.; LU, Y.F.; INBARAI, S.B.; CHEN, B.H. Determination of phenolic acids and flavonoids in Rhinacanthus nasutus (L.) kurz by high-performance-liquid-chromatography with photodiode-array detection and tandem mass spectrometry. Journal of Functional Foods, London, v.12, p.498-508, 2015.

IMEH, U.; KHOKHAR, S. Distribution of Conjugated and Free Phenols in Fruits: Antioxidant Activity and Cultivar Variations. Journal of Agricultural and Food Chemistry, Washington, v.50, p.6301- 6306, 2002.
KARAKAYA, S. Bioavailability of phenolic compounds. Critical Reviews of Food Science Nutrition, Boca Raton, v. 44, n. 6, p. 453-64, 2004.

LIMA, T.B.; SILVA, O.N.; OLIVEIRA, J.T.; VASCONCELOS, I.M.; SCALABRIN, F.B.; ROCHA, T.L.; GROSSI de SÁ, M.F.; SILVA, L.P.; GUADAGNIN, R.V.; QUIRINO, B.F.; CASTRO, C.F.; LEONARDECZ, E.; FRANCO, O.L. Identification of $E$. dysenterica laxative peptide: A novel strategy in the treatment of chronic constipation and irritable bowel syndrome. Peptides, New York, v.31, n.8, p.1426-1433, 2010.

MALAVOLTA, E.; PIMENTEL GOMES, F.; ALCARDE, L.C. Adubos e adubações. São Paulo: Nobel, 2002. 200p.

MITTAL, A.K.; KUMAR, S.; BANERJEE, U.C. Quercetin and gallic acid mediated synthesis of bimetallic (silver and selenium) nanoparticles and their antitumor and antimicrobial potential. Journal of Colloid and Interface Science, Orlando, v.431, p.194-199, 2014.

MORGANO, M.A.; QUEIROZ, S.C.N.; FERREIRA, M.M.C. Determinação dos teores de minerais em sucos de frutas por espectrometria de emissão óptica em plasma indutivamente acoplado (ICP-OES). Ciências e Tecnologia de Alimentos, Campinas, v.19, p.344-348, 1999.

NIELSEN, F.H. Atualização sobre efeitos na saúde humana de boro. Journal of Trace Elements in Medicine and Biology, New York, v.28, n.4, p.383$387,2014$.

NINFALI, P.; MEA, G.; GIORGINI, S.; ROCCHI, M.; BACCHIOCCA, M. Antioxidant capacity of vegetables, spices and dressings relevant to nutrition. British Journal of Nutrition, Wallingford, v.93, n 2, p. 257-66, 2005.

OETTERER, M.; D'ARCE, M. A. B. R.; SPOTO, M. Fundamentos de ciência e tecnologia de alimentos. São Paulo: Manole, 2006. 664p. 
ROCHA, M. S.; FIGUEIREDO, R.W de.; ARAÚJO, M.A da M.; MOREIRA-ARAÚJO, R.S dos R.;. Caracterização físico-química e atividade antioxidante (in vitro) de frutos do cerrado piauiense. Revista Brasileira de Fruticultura, Jaboticabal, v.35, n.4, p.933-941, 2013.

ROCHA, W.S.; LOPES, R,M.; SILVA, D.B da.; VIEIRA, R.F.; SILVA, J.P da.; COSTA, T. da. S.A. Compostos fenólicos totais e taninos condensados em frutas nativas do cerrado. Revista Brasileira Fruticultura, Jaboticabal, v. 33, n.4, p.1215-1221, 2011.

ROESLER, R.; MATA, L.G.; CARRASCO, L.C.; HOLANDA'R.B.; SOUSA, C.A.S.; PASTORE, G.M.P. Atividade antioxidante de frutas do cerrado. Ciência Tecnologia de Alimentos, Campinas, v.27, n.1, pp.53-60, 2007.

ROSS, A.C.; CABALlERO, B.; COUSINS, R.J.; TUCKER, K.L.; ZIEGLER, T.R. Modern nutrition in health and disease. $11^{\text {th }}$ ed. Philadelphia: Wolters Kluwer Health, 2014. 1616p.

SELVARAJ, Y.; KUMAR, R. Studies on fruit softening enzymes and polyphenol oxidase activity in ripening mango (Mangifera indica L.) fruit. Journal of Food Science and Technology, Mysore, v.26, n.4, p.218-222, 1989.

SHIN, D.; JOH, H.K.; KIM, H.H.; PARQUE, S.M. Benefits of potassium intake on metabolic syndrome: The fourth Korean National Health and Nutrition Examination Survey (KNHANES IV). Atherosclerosis, Netherlands, v.230, n.1, p.80-85, 2013.
SILVA, M.R.; LACERDA, D.B.C.L.; SANTOS, G.G.;MARTINS, D.M de O. Caracterização química de frutos nativos do cerrado. Ciência Rural, Santa Maria, v.38, n.6, p.1790-1793, 2008.

SILVA, R. S.M.; CHAVES, L. J.; NAVES, R.V. Caracterização de frutos e árvores de cagaita (Eugenia dysenterica dc.) no sudeste do estado de Goiás, Brasil. Revista Brasileira Fruticultura, Jaboticabal, v. 23, n. 2, p. 330-334, 2001.

TAIZ, L.; ZEIGER, E. Fisiologia vegetal. 4.ed. Porto Alegre: Artmed, 2009. 819p.

VANILLO, M.I.; LAMARDO, L.C.A.; GABERLOTTI, E.O.; MORENO, P.R.H. Composição química dos frutos de Campomanesia adamantiumm (Cambessédes) O. BERG. Ciência e Tecnologia de Alimentos, Campinas, v.26, n.4, p.805-810, 2006.

VIEIRA, P.M.; VERONEZI, E.; SILVA, C .R.; CHEN-CHEN, L. Detection of genotoxic, cytotoxic, and protective activities of Eugenia dysenterica DC. (Myrtaceae) in mice. Journal of Medicinal Food, New York, v.15, n.6, p.563-567, 2012.

WENZEL U. Flavonoids as drugs at the small intestinal level. Current Opinion in Pharmacology, Oxford, v.13, p.864-868, 2013. 